\title{
Thermal and mechanical structure of the central Iberian Peninsula lithosphere
}

\author{
Rosa Tejero*, Javier Ruiz \\ Departamento de Geodinámica, Facultad de Ciencias Geologicas, Universidad Complutense, 28040 Madrid, Spain
}

\begin{abstract}
The central Iberian Peninsula (Spain) is made up of three main tectonic units: a mountain range, the Spanish Central System and two Tertiary basins (those of the rivers Duero and Tajo). These units are the result of widespread foreland deformation of the Iberian plate interior in response to Alpine convergence of European and African plates. The present study was designed to investigate thermal structure and rheological stratification in this region of central Spain. Surface heat flow has been described to range from $\sim 80$ to $\sim 60 \mathrm{~mW} \mathrm{~m}^{-2}$. Highest surface heat flow values correspond to the Central System and northern part of the Tajo Basin. The relationship between elevation and thermal state was used to construct a one-dimensional thermal model. Mantle heat flow drops from $34 \mathrm{~mW} \mathrm{~m}^{-2}$ (Duero Basin) to $27 \mathrm{~mW} \mathrm{~m}^{-2}$ (Tajo Basin), and increases with diminishing surface heat flow. Strength predictions made by extrapolating experimental data indicate varying rheological stratification throughout the area. In general, in compression, ductile fields predominate in the middle and lower crusts and lithospheric mantle. Brittle behaviour is restricted to the first $\sim 8 \mathrm{~km}$ of the upper crust and to a thin layer at the top of the middle crust. In tension, brittle layers are slightly more extended, while the lower crust and lithospheric mantle remain ductile in the case of a wet peridotite composition. Discontinuities in brittle and ductile layer thickness determine lateral rheological anisotropy. Tectonic units roughly correspond to rheological domains. Brittle layers reach their maximum thickness beneath the Duero Basin and are of least thickness under the Tajo Basin, especially its northern area. Estimated total lithospheric strength shows a range from $2.5 \times 10^{12}$ to $8 \times 10^{12} \mathrm{~N} \mathrm{~m}^{-1}$ in compression, and from $1.3 \times 10^{12}$ to $1.6 \times 10^{12} \mathrm{~N} \mathrm{~m}^{-1}$ in tension. Highest values were estimated for the Duero Basin. Depth versus frequency of earthquakes correlates well with strength predictions. Earthquake foci concentrate mainly in the upper crust, showing a peak close to maximum strength depth. Most earthquakes occur in the southern margin of the Central System and southeast Tajo Basin. Seismicity is related to major faults, some bounding rheological domains. The Duero Basin is a relative quiescence zone characterised by higher total lithospheric strength than the remaining units.
\end{abstract}

Keywords: Thermal structure; Mechanical structure; Central Iberian Peninsula; Rheological profiles; Seismicity

\section{Introduction}

Integrated geological and geophysical observations and laboratory experiments have improved current understanding of the rheology of the continental lithosphere. Experimental investigations centred on the deformation properties of several rocks have yielded rheological laws related to the first-order mechanical behaviour of the continental crust (e.g., Brace and Kohlstedt, 1980; Kuznir and Park, 1984; Carter and Tsenn, 1987; Kirby and Kronenberg, 1987; Tsenn and 
Carter, 1987; Ranalli, 1997). Different lithologies at varying depths, each with characteristic mechanical properties and deformational responses to a given regime of temperature, pressure, strain rate and fluid pressure, lend supports to the phenomenon of rheological stratification of the lithosphere. This stratification is characterised by alternating brittle and ductile layers with the possibly of more than one brittleductile transition (e.g., Ranalli and Murphy, 1987). Besides this depth-dependent rheology of the continental lithosphere, significant lateral variations arise from different crust structures and thermal regimes. These variations provoke rheological anisotropy, a main factor controlling the behaviour of the lithosphere
(Lowe and Ranalli, 1993; Cloetingh and Burov, 1996; Hyndman and Lewis, 1999; Lankreijer et al., 1999).

The Iberian Plate region is ideal for exploring the effects of variables, such as surface heat flow and crustal structure on the rheology of the lithosphere. Rheological profiles of its northeastern part indicate different strength distributions for different tectonic units including an Alpine range (Pyrenees) and two Neogene basins, the Ebro Basin and the Valencia Trough (Zeyen and Fernández, 1994). The interior Iberian Peninsula comprises an intraplate mountain range and two intracontinental sedimentary basins formed during alpine tectonics events. The aim of this paper was to model the thermal structure and

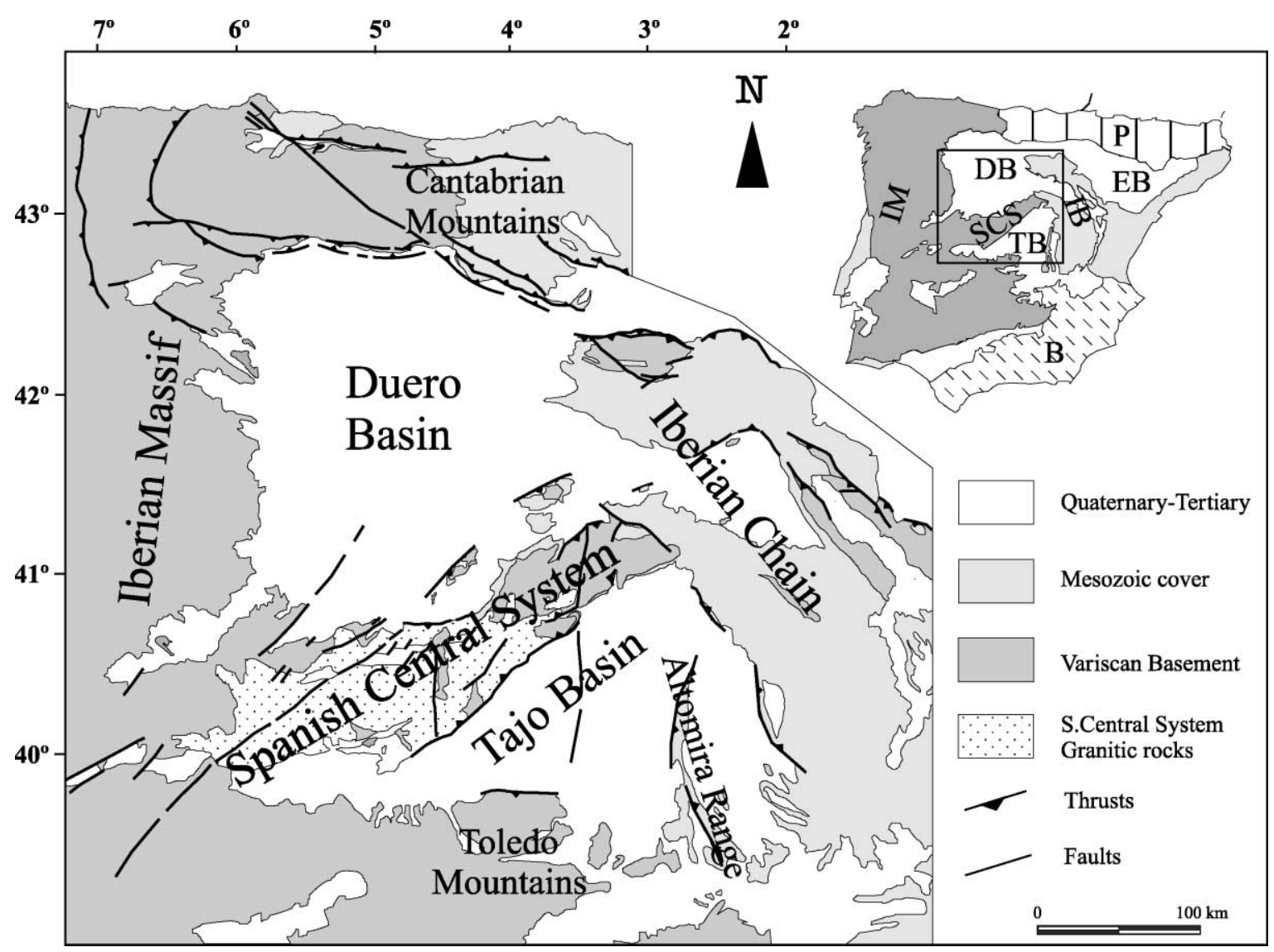

Fig. 1. Geological and geographical settings of the study area. The Duero and Tajo basins bound the Spanish Central System, a mountain range formed by a Variscan basement. Main tectonic units of the Iberian Peninsula: Pyrenees (P), Ebro Basin (EB), Iberian Massif (IM), Spanish Central System (SCS), Iberian Range (IB), Tajo Basin (TB), Betics (B). 
lithospheric rheology of the central Iberian Peninsula (Fig. 1). Documented heat flow and seismic data were used to construct one-dimensional thermal models for the different tectonic units. Strength profiles extrapolated from rock mechanics data allow us to approach a first-order strength distribution for the area. Results are discussed with particular reference to seismic data.

\section{Geological setting}

The Iberian Plate is an example of far-field stress giving rise to intraplate deformation, far from plate active boundaries. During the Late Cretaceous and Tertiary, the convergence of Africa and Eurasia caused the deformation of Iberian plate palaeo-margins. Within this collision setting, the Pyrenees and Cantabrian Mountains in the north and Betics in the south were built up. Contemporaneously, an intraplate range and two subaerial Cainozoic basins developed in the central Iberian Peninsula. These from north to south are: the Duero Basin, the Spanish Central System and the Tajo Basin (Fig. 1).

The Duero Basin is an intracontinental basin filled with Tertiary sediments. High-relief mountains made up of igneous and metamorphic rocks of Variscan basement and carbonate rocks of Mesozoic age bound the Duero Basin. Its tectonic progression is related to the tectonic development of its borders (Santisteban et al., 1996). To the north, it comprises the foreland basin formed at the southern tectonic front of the Cantabrian Mountains (Alonso et al., 1996). Up to $2000 \mathrm{~m}$ of Tertiary sediments were deposited in the mountain foreland associated with a syndepositional thrust-related front. The Iberian Range constitutes the eastern border. This NW-SE intraplate mountain range was the consequence of pre-Alpine sedimentary basin inversion (Alvaro et al., 1979). In the western border, igneous and metamorphic rocks of the Iberian Massif bound the Duero Basin. Here, N- and NEtrending faults condition Tertiary sediment distribution. In the basin's southern zone, magnetic data indicate that structure is characterised by uplifted and depressed fault bounded blocks, where sedimentary infill can reach up to $2000 \mathrm{~m}$ (Aeroservice, 1964). These structures are related to the alpine development of the Spanish Central System. This NE-SW moun- tain range covers over $350 \mathrm{~km}$, reaching altitudes up to $2000 \mathrm{~m}$. A Variscan basement pertaining to the Iberian Massif outcrops extensively in this range and is composed mainly of metamorphic and igneous rocks. Granitic rocks dominate its western zone, while metamorphic rocks prevail in the east (Fig. 1). Basement-involved reverse faults characterise its Alpine structure (e.g., De Vicente et al., 1996b). Most of these are inherited structures reactivated in alpine deformation stages. Within the mountain range, small intramountain basins preserve Mesozoic and Tertiary sediments. Several models have been proposed to explain the formation of the Spanish Central System. It has been described as a pop-up structure (Warburton and Álvarez, 1989; De Vicente et al., 1992; Tejero et al., 1996) or as a flower structure (Portero and Aznar, 1984) and attributed to simultaneous strike-slip faulting and block rotation (Vegas et al., 1990).

The Tajo Basin extends to the south of the Central System. Two basin depocentres, where sediment thickness is as high as $3000 \mathrm{~m}$ (Querol, 1989), are located close to its north and northeastern borders. These depocenters are associated with the Iberian Chain and Central System uplift. The Sierra de Altomira, a branch of the Iberian Chain, borders the Tajo Basin to the east as a west-verging fold-and-thrust belt. These structures occur above a detachment level found in evaporitic horizons of Upper Triassic age (Alvaro et al., 1979; Viallard, 1983; Muñoz Martín and De Vicente, 1998). The main southern structural unit in the study area is formed by the Toledo Mountains, a Variscan basement uplifted block. A reverse, E-Wtrending fault defines the limits between the Tajo Basin and Variscan basement rocks (e.g. De Vicente et al., 1996b).

Seismic refraction experiments performed in the central Iberian Peninsula indicate a three-layer crust structure with a 14-km thick upper crust, 9-km middle crust and 8-km lower crust (Banda et al., 1981; Suriñach and Vegas, 1988; ILIHA DSS Group, 1993; Gallart et al., 1995; Pulgar et al., 1996). The Moho occurs at an average depth of $31 \mathrm{~km}$. Seismic data suggest no significant lateral variation, except under the Central System. Beneath this mountain range, the crust thickens and the Moho reaches a depth of $34 \mathrm{~km}$. According to the seismic model of Suriñach and Vegas (1988), the upper crust arches upwards and the middle-lower crust boundary and 
Moho show a downward deflection under the mountain range. Crustal thickening is attributed to alpine deformation (Suriñach and Vegas, 1988; Vegas et al., 1990).

\section{Thermal modelling}

The thermal structure of the lithosphere depends on surface heat flow, heat source distribution and the thermal conductivity of lithospheric rocks. Surface heat flow over a continental crust may be described to have two components: radiogenic heat generated within the crust and heat dissipation from the mantle. Thus, heat production needs to be known to estimate geotherms. Fernández et al. (1998) recently published updated heat flow and heat production maps of the Iberian Peninsula. Despite irregular sampling surface distribution, the heat flow map of the Iberian Peninsula indicates variations in the study area. According to this map, in the central Iberian Peninsula, surface heat flow ranges from $\sim 60$ to $\sim 80 \mathrm{~mW} \mathrm{m^{2 }}$. Maximum surface heat flow, up to $80 \mathrm{~mW} \mathrm{~m}^{-2}$, corresponds to a zone around the Central System-Tajo Basin boundary. This mountain range is characterised by a mean of $70 \mathrm{~mW} \mathrm{~m}^{-2}$ surface heat flow. To the north and south, surface heat flow drops to $<70 \mathrm{~mW} \mathrm{~m}^{-2}$. As mentioned above, granitic rocks outcrop extensively in the Central System, while geophysical data suggest that metamorphic rocks prevail in the basement underlying the Duero and Tajo basins (Aeroservice, 1964; Querol, 1989). Average heat production for granitic rocks has been quoted as $3.26 \mu \mathrm{W} \mathrm{m} \mathrm{m}^{-3}$, higher than values for metamorphic rocks, which range from $\sim 0.8$ to $\sim 2.3 \mu \mathrm{W} \mathrm{m}$ m $^{-3}$ (Fernández et al., 1998). Thus, relatively low differences in heat flow values may be related to upper crust composition (Lachenbruch, 1968, 1970).

As might be expected, there is considerable uncertainty with regard to middle and lower crust heat production. Unknown rock succession in depth compelled us to consider layer homogeneity. Since heat production is related to lithology, crustal layer lithologic heterogeneity leads to over- or underestimation of the contribution of this factor. Seismic velocities and petrologic findings point to a granodioritic composition of the middle crust (Banda et al., 1981; Villaseca et al., 1999). Xenolith studies performed in the Spanish Central System indicate a felsic granulite composition of the lower crust and a heat production value of $\sim 0.8 \mu \mathrm{W} \mathrm{m}{ }^{-3}$ (Villaseca et al., 1999).

The following simplified assumptions were made to calculate the temperature profile: (a) the lithosphere is in thermal equilibrium; (b) heat sources in the crust are distributed among three layers, plus a layer representing sedimentary infill in the basins; (c) heat is transported by conduction; (d) layers (crust and mantle) show exponential heat production decay, except the sedimentary layer of basin infill, where a constant heat production decrease was assumed.

If an exponential decay with depth of heat production $A$ is assumed then, $A=A_{0} \exp (-h / D)$, where $A_{0}$ is the heat produced at the top of the layer, $h$ is the depth below the layer surface and $D$ is the exponential decay constant ( $D$ represents depth where $A=A_{0} / e$ ). Temperature is determined according to the equation:

$T=T_{0}+\frac{F_{\mathrm{r}}}{k} h+\frac{A D^{2}}{k}\left[1-\exp \left(\frac{-h}{D}\right)\right]$,

where $T_{0}$ is the temperature at the top of the layer, $F_{\mathrm{r}}$ is the reduced heat flow and $k$ is the thermal conductivity. If a continental geotherm with exponential radiogenic heat source distribution is considered then, reduced heat flow, $F_{\mathrm{r}}$, is calculated as (Lachenbruch, 1968, 1970):

$F_{\mathrm{r}}=F_{0}-A_{0} D$

where $F_{0}$ is the heat flow at the top of the layer. However, if radiogenic heat sources of different radiogenic element distribution underlie a layer of heat production of exponential distribution, heat production at the base of a layer of thickness $b$ is $A_{\text {base }}=$ $A_{0} \exp (-b / D)$. Thus, a effective reduced heat flow can be expressed as:

$F_{\mathrm{r}}=F_{0}-A_{0} D\left[1-\exp \left(\frac{-b}{D}\right)\right]$.

Otherwise, for a constant heat production model, the temperature profile of any layer is:

$T=T_{0}+\frac{F_{0}}{k} h-\frac{A}{2 k} h^{2}$.

To reduce the uncertainty of temperature estimates, we constrained thermal structure using the relationship between elevation and thermal regime proposed by Lachenbruch and Morgan (1990). According to 
these authors, a column of solid lithosphere of height $b_{1}$ and mean density $\rho_{1}$ is in a floating equilibrium over a fluid asthenosphere of density $\rho_{\mathrm{a}}$. Elevation above sea level $(e)$ is expressed by:

$e=H_{\mathrm{c}}+H_{\mathrm{m}}-H_{0}$,

where $H_{\mathrm{c}}$ and $H_{\mathrm{m}}$ are the individual contributions of crust and mantle components to the buoyancy of the lithosphere. $H_{0}$ is the buoyant height of sea level above the free asthenosphere surface $\left(H_{0} \cong 2.4 \mathrm{~km}\right.$; Lachenbruch and Morgan, 1990). Crust contribution is estimated from:

$H_{\mathrm{c}}=\frac{1}{\rho_{\mathrm{a}}}\left(\rho_{\mathrm{a}}-\rho_{\mathrm{c}}\right) b_{\mathrm{c}}$,

where $b_{\mathrm{c}}$ is crust thickness and $\rho_{\mathrm{c}}$ is mean crust density. Mantle contribution is related to the thermal state of the lithosphere mantle by:

$H_{\mathrm{m}}=-\alpha\left(T_{\mathrm{a}}-\bar{T}_{\mathrm{m}}\right) b_{\mathrm{m}}$,

where $\alpha$ is the thermal volumetric expansion coefficient, $b_{\mathrm{m}}$ is the lithosphere mantle thickness, $T_{\mathrm{a}}$ is the asthenosphere temperature (assumed an isotherm) and $T_{\mathrm{m}}$ is the mean lithospheric mantle temperature given by:

$\bar{T}_{\mathrm{m}}=\frac{1}{b_{\mathrm{m}}} \int_{0}^{b_{\mathrm{m}}} T(h) \mathrm{d} h$,

where $T(h)$ is determined from Eqs. (1) and (2). Here, we assumed a temperature at the lithosphere-asthenosphere boundary of $1350{ }^{\circ} \mathrm{C}$, an asthenosphere density of $3200 \mathrm{~kg} \mathrm{~m}^{-3}$ and a thermal volumetric expansion coefficient of $3.5 \times 10^{-5} \mathrm{~K}^{-1}$. The value of the exponential decay constant, $D$, is 12 .

Crustal structure and composition derived from seismic data, surface heat flow and the assumption of local isostasy were used to construct several onedimensional geotherms for the central Iberian Peninsula. The mantle heat flow was estimated by subtracting crustal contribution from surface heat flow. Table 1 summarises the variables used in the estimations. Fig. 2 shows a topographic profile corresponding to the central part of the Spanish Central System close to adjacent basin areas. Mean elevation of the Duero Basin calculated was $\sim 800 \mathrm{~m}$, and heights of $\sim 1250$

Table 1

Parameters used to construct the geotherms

\begin{tabular}{|c|c|c|c|c|}
\hline & $\begin{array}{l}\text { Thickness } \\
(\mathrm{km})\end{array}$ & $\begin{array}{l}\text { Density } \\
\left(\mathrm{kg} \mathrm{m}^{-3}\right)\end{array}$ & $\begin{array}{l}\text { Thermal } \\
\text { conductivity } \\
\left(\mathrm{W} \mathrm{m}^{-1} \mathrm{~K}^{-1}\right)\end{array}$ & 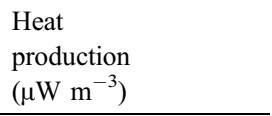 \\
\hline \multicolumn{5}{|l|}{ Duero Basin } \\
\hline Sediments layer & 1 & 2400 & 2.5 & 2.5 \\
\hline Upper crust & 13 & 2700 & 2.5 & 1.8 \\
\hline Middle crust & 9 & 2850 & 2.5 & \\
\hline Lower crust & 8 & 2900 & 2.1 & 0.8 \\
\hline \multicolumn{5}{|c|}{ Spanish Central System } \\
\hline Upper crust & 11 & 2670 & 2.5 & 3.3 \\
\hline Middle crust & 14 & 2800 & 2.5 & \\
\hline Lower crust & 9 & 2900 & 2.1 & 0.8 \\
\hline \multicolumn{5}{|l|}{ Tajo Basin } \\
\hline \multirow[t]{2}{*}{ Sediments layer } & 2 & 2400 & 2.5 & 2.5 (H.F. $70 \mathrm{~mW} \mathrm{~m}^{-2}$ ) \\
\hline & 1 & 2400 & 2.5 & 2.5 (H.F. $65 \mathrm{~mW} \mathrm{~m}^{-2}$ ) \\
\hline \multirow[t]{2}{*}{ Upper crust } & 12 & 2700 & 2.5 & 3.3 (H.F. $70 \mathrm{~mW} \mathrm{~m}^{-2}$ ) \\
\hline & 13 & 2700 & 2.5 & 2.5 (H.F. $65 \mathrm{~mW} \mathrm{~m}^{-2}$ ) \\
\hline Middle crust & 9 & 2850 & 2.5 & \\
\hline Lower crust & 8 & 2900 & 2.1 & 0.8 \\
\hline
\end{tabular}

In all cases, thermal conductivity of lithospheric mantle is $3.4 \mathrm{~W} \mathrm{~m}^{-1} \mathrm{~K}^{-1}$. 


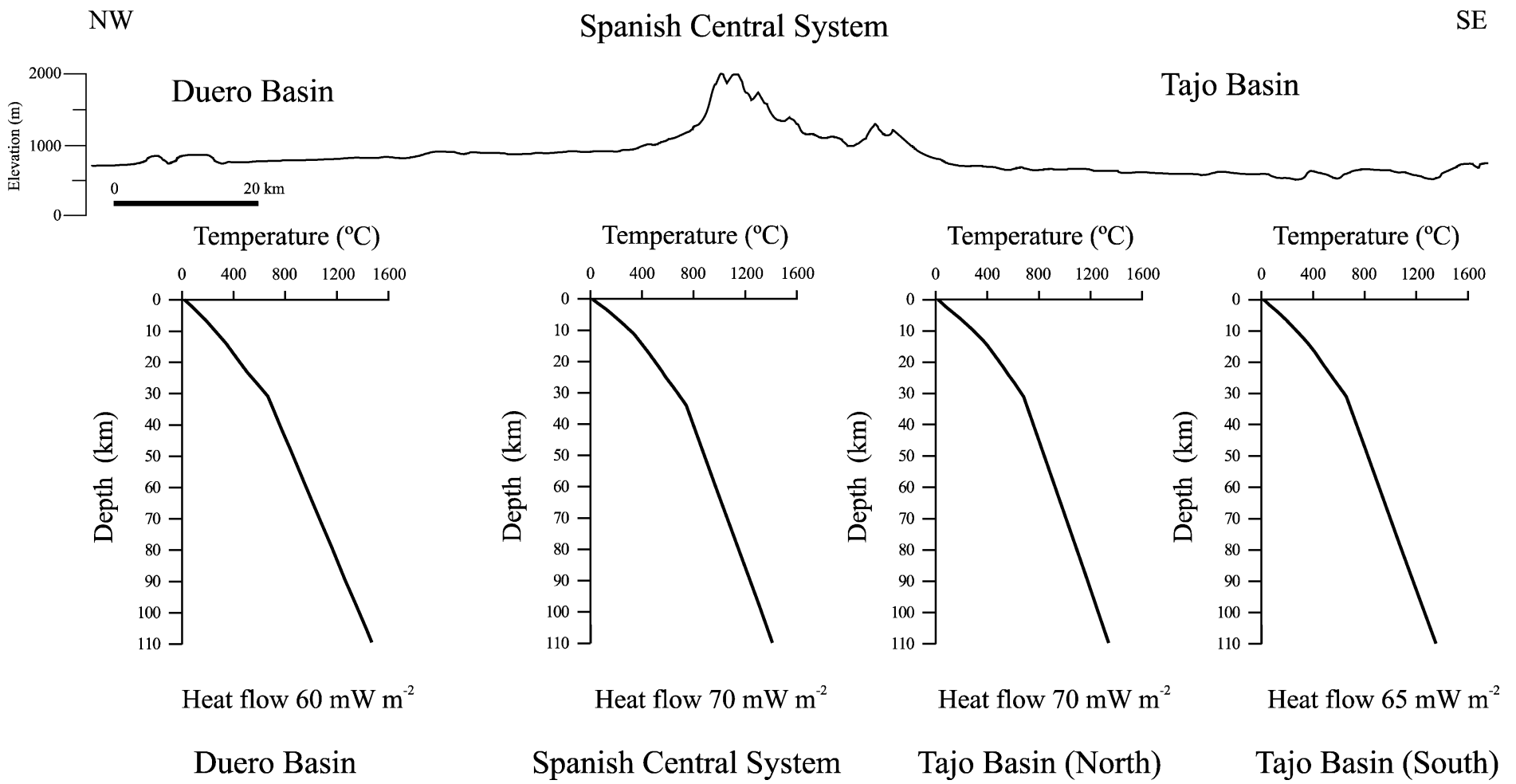

Fig. 2. Calculated geotherms plotted along a NW-SE transverse section of the area. Variables used in estimations are provided in Table 1. See text for details. 
$\mathrm{m}$ for the Central System and $\sim 650 \mathrm{~m}$ for the Tajo Basin. A $\pm 30 \mathrm{~m}$ deviation was assumed.

\section{Results of thermal modelling}

Geotherms for the Central System and Tajo and Duero basins were constructed for different surface heat flow data. Calculations using surface heat flows of 80 and $50 \mathrm{~mW} \mathrm{~m}^{-2}$ showed deviations from mean elevation data greater than $\pm 500 \mathrm{~m}$ and were consequently not considered for thermal and rheological purposes. For example, a surface heat flow of $80 \mathrm{~mW}$ $\mathrm{m}^{-2}$ was determined at an oil well in the Tajo Basin near the Central System boundary. In this particular case, good fit was achieved assuming lithosphere and crust thicknesses lower than those of surrounding areas. This feature is inconsistent with the seismic model (Suriñach and Vegas, 1988). Moreover, surface heat flow is measured over a Tajo Basin depocentre, where water movement can influence the heat flow pattern, as suggested for other sedimentary basins (e.g., Majorowicz et al., 1984). Mean elevation best fit is achieved using the following surface heat flow values: $60 \mathrm{~mW} \mathrm{~m}^{-2}$ for the Duero Basin, $70 \mathrm{~mW} \mathrm{~m}^{-2}$ for the Central System, $70 \mathrm{~mW} \mathrm{~m}^{-2}$ for the northern region of the Tajo Basin and $65 \mathrm{~mW} \mathrm{~m}^{-2}$ for the southern Tajo Basin area. Calculated elevation misfits are: $-10 \mathrm{~m}$ (Duero Basin), $-20 \mathrm{~m}$ (Central System), $+30 \mathrm{~m}$ (Northern Tajo Basin) and $+40 \mathrm{~m}$ (Southern Tajo Basin) (Fig. 2).

Upper and middle crust densities in the different units were adjusted to fit elevation data. For the Central System, the model was constructed assuming upper and middle crust densities of 2670 and $2800 \mathrm{~kg}$ $\mathrm{m}^{-3}$, respectively, whereas beneath the basins, densities of 2700 and $2850 \mathrm{~kg} \mathrm{~m}^{-3}$ were considered. Geologic, gravity and magnetic data suggest that metasediments are more abundant within the basement underlying the basins, and less dense rocks, such as granite, predominate in the Central System (Aeroservice, 1964; Querol, 1989).

At Moho depth, lower temperatures were found for the Duero $\left(650{ }^{\circ} \mathrm{C}\right)$ and Tajo $\left(650{ }^{\circ} \mathrm{C}\right.$, surface heat flow $65 \mathrm{~mW} \mathrm{~m}^{-2}$ ) basins. At the same depth, for a surface heat flow of $70 \mathrm{~mW} \mathrm{~m}^{-2}$, temperature rises to $740{ }^{\circ} \mathrm{C}$ in the Spanish Central System and $680{ }^{\circ} \mathrm{C}$ in the Tajo Basin. Mantle heat flow increases with descending surface heat flow and ranges from $34 \mathrm{~mW} \mathrm{~m}^{-2}$ in the Duero Basin $\left(60 \mathrm{~mW} \mathrm{~m}^{-2}\right)$ to 27 and $29 \mathrm{~mW} \mathrm{~m}^{-2}$ in the Tajo Basin (70 and $65 \mathrm{~mW} \mathrm{~m}^{-2}$, respectively). These values are similar to those obtained for alpine terrain (e.g., Cermak, 1989). In consequence, the lithosphereasthenosphere boundary rises to $98 \mathrm{~km}$ to account for the elevation in the Duero Basin, whereas in the Tajo Basin it is located at $110 \mathrm{~km}$.

\section{Lithospheric strength}

Laboratory experiments have demonstrated the dependence of rock strength on temperature and pressure. In the upper crust, where temperature and pressure are low, mechanical behaviour is governed by brittle failure. At temperatures higher than about one-half of their solidus, all rocks are ductile. Using the concept of strength envelopes, we can model the strength of the crust by means of a brittle frictional failure criterion and a ductile flow law (Ranalli and Murphy, 1987). Thus, the strength of the lithosphere at any depth is the minimum between the strengths of brittle and ductile deformation.

Assuming a prefractured medium, the magnitude of the differential stress required for fault reactivation is:

$\sigma_{\text {diff }}=\beta P(1-\lambda)$

where $\beta$ is a factor that depends on the tectonic regime, $P$ is the lithostatic pressure and $\lambda$ is the pore fluid factor defined as the ratio of pore fluid pressure to lithostatic pressure (Sibson, 1974). For one layer, the lithostatic pressure increase with depth may be defined as $\mathrm{d} P=\rho_{i} g \mathrm{~d} h$, where $\rho_{i}$ is the density of the layer.

Ductile deformation of the lithosphere is assumed to be dominated by dislocation creep and, thus, its mechanical behaviour is governed by a nonlinear viscous law (e.g., Brace and Kohlstedt, 1980; Carter and Tsenn, 1987; Tsenn and Carter, 1987). If the composition and the temperature profile are known, the minimum differential stress needed to maintain a given strain rate is given by:

$$
\sigma_{\text {diff }}=\left(\frac{\varepsilon}{A}\right)^{1 / n} \exp \left(\frac{Q}{n R T}\right)
$$




\begin{tabular}{llll} 
Table 2 & & & \\
\hline $\begin{array}{l}\text { Creep } \\
\text { parameters }\end{array}$ & $\begin{array}{l}A \\
\left(\mathrm{MPa}^{-n} \mathrm{~s}^{-1}\right)\end{array}$ & $\begin{array}{l}Q \\
\left(\mathrm{~kJ} \mathrm{~mol}^{-1}\right)\end{array}$ & $n$ \\
\hline Dry quarzite & $6.7 \times 10^{-6}$ & 156 & 2.4 \\
Wet quarzite & $3.2 \times 10^{-4}$ & 154 & 2.3 \\
Dry granite & $1.8 \times 10^{-9}$ & 123 & 3.2 \\
Wet granite & $2.0 \times 10^{-4}$ & 137 & 1.9 \\
Quarzdiorite & $1.3 \times 10^{-3}$ & 219 & 2.4 \\
Felsic granulite & $8.0 \times 10^{-3}$ & 243 & 3.1 \\
Dry peridotite & $2.5 \times 10^{4}$ & 532 & 3.5 \\
Wet peridotite & $2.0 \times 10^{3}$ & 471 & 4.0
\end{tabular}

From Ranalli (1997).

where $\varepsilon$ is the strain rate, $A$ and $n$ are material constants, $Q$ is the activation enthalpy for creep, $R$ is the gas constant and $T$ is temperature.

Expressions (9) and (10) were used to calculate four strength profiles corresponding to calculated geotherms. We adopted a five-layer rheological model for the lithosphere: a sedimentary layer only present in basins, a quartzite or granite layer (representing the upper crust), a quartzdiorite layer (middle crust), a felsic granulite layer (lower crust) and a peridotite layer representing the lithospheric mantle. The $\beta$ values are 0.75 for tensional stress and 3 for compression stress. Calculations were performed for $\lambda=0.4$. Rheological profiles are calculated for a strain rate of $10^{-15} \mathrm{~s}^{-1}$. Table 2 summarises the material properties of these lithologies.

\section{Rheological stratification of the lithosphere in the central Iberian Peninsula}

Brittle-ductile transition is always represented by a change from brittle frictional to dislocation creep deformation. Under tensional stress, two brittle-ductile transitions appear, except for the higher surface heat flow value of the Tajo Basin (Fig. 3). Upper transition occurs within the upper crust at a mean depth of $8 \mathrm{~km}$ for wet quartzite and $10 \mathrm{~km}$ for dry quartzite. It shallows to $6 \mathrm{~km}$ for the wet granite composition of the upper crust of the Spanish Central System. The lower transition is found in the middle crust at a $16 \mathrm{~km}$ depth beneath the basins and at $14 \mathrm{~km}$ under the mountain range. In compression stress, only a brittle-ductile transition appears and is restricted to the upper crust. It is shallower beneath the Tajo Basin for a surface heat flow of $70 \mathrm{~mW} \mathrm{~m}{ }^{-2}$, where it is located at a 6-km depth for wet quartzite and $8 \mathrm{~km}$ for dry quartzite, and deepens to 8 and $10 \mathrm{~km}$ for wet and dry quartzite underlying the Duero Basin, respectively. All the rheological profiles showed a ductile lower crust that was always softer than the uppermost mantle.

The lithospheric mantle remained in the ductile field for a wet peridotite composition of the whole area. For dry peridotite and tensional stresses, brittleductile transition takes place at a mean depth of $36 \mathrm{~km}$. Only dry peridotite lithology and tensional stresses determine strength discontinuity between the lower crust and lithospheric mantle in each case (Fig. 3). Under compression conditions, the lithospheric mantle presents ductile behaviour. Moho does not represent a strong mechanical discontinuity as observed in other Variscan and Alpine lithospheres (e.g., Cloetingh and Burov, 1996).

Using the relationship between yielding strength and lithostatic pressure, we estimated competent layer thicknesses. According to Cloetingh and Burov (1996), depth to the base of the competent layer can be defined as the depth at which strength is under $1-5 \%$ of the lithostatic pressure, and the vertical differential stress gradient is less than 10-15 MPa. Results show that the upper and middle crusts mostly behave as competent layers, while the lower crust represents an incompetent layer. The base of the competent layer is at a depth of 19 $\mathrm{km}$ under the Central System, and deepens to $21 \mathrm{~km}$ beneath the Duero Basin. In the basins, the base of the lithospheric mantle competent layer reaches a mean depth of 48 and $36 \mathrm{~km}$ for dry and wet peridotite, respectively. In the Central System, base depths decreases to 42 and $33 \mathrm{~km}$ for dry and wet peridotite, respectively (Fig. 3).

In summary, the crust is formed by an upper competent layer that extends to a mean depth of 20 $\mathrm{km}$ and a lower incompetent layer (Fig. 3). For wet compositions, a 2-km thick incompetent layer occurs between the upper and middle crust. The lithosphere mantle presents an upper competent layer that extends to depths of 46 and $36 \mathrm{~km}$ depending on whether its composition is dry or wet peridotite.

Integrating the rheological profile yields a total lithospheric strength (Ranalli, 1997). Fig. 4 provides total lithospheric strength estimates for compression 
Duero Basin

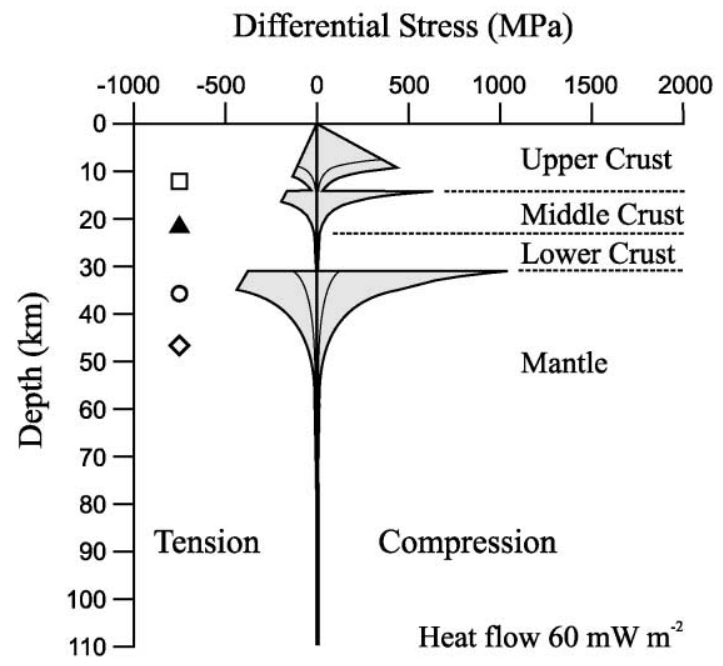

\section{Spanish Central System}

Differential Stress (MPa)

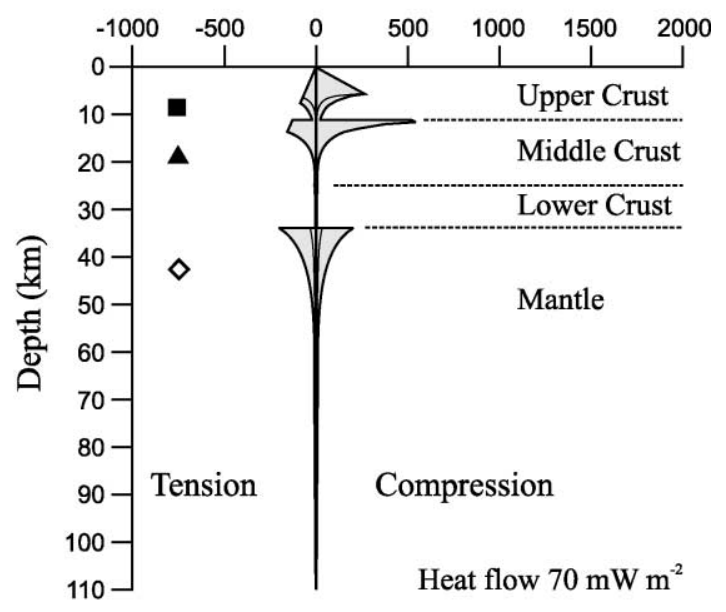

\section{Tajo Basin}
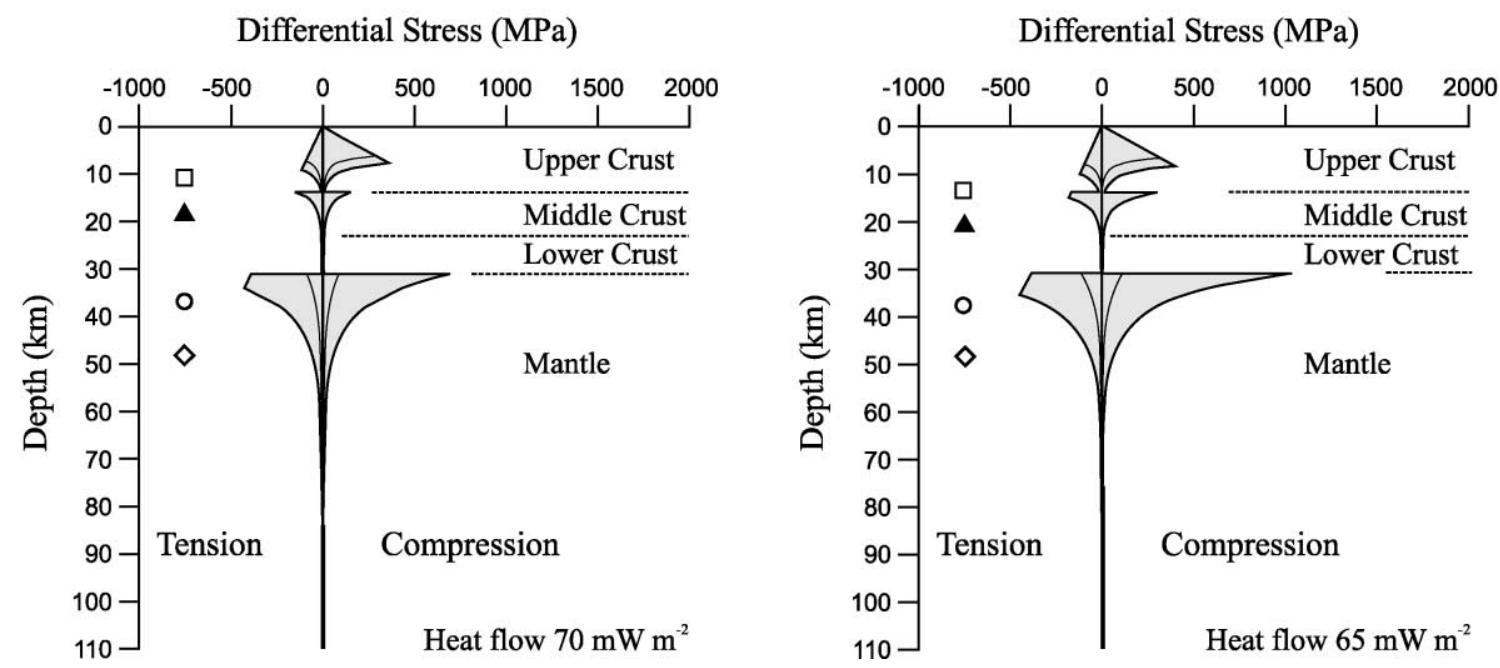

Fig. 3. Rheological profiles in tension and compression at a strain rate of $10^{-15} \mathrm{~s}^{-1}$. Outer black line binds differential stress estimated for dry rock composition. Inner black line denotes differential stress for wet rock composition of the upper crust (quartzite or granite) and lithospheric mantle (peridotite). See Table 1 for rheological variables. Geometric symbols mark the base of competent layers for the upper, middle and lower crust, as well as the lithospheric mantle. Only wet rock data are shown for the upper crust. ( $\square$ ) Wet quartzite; (ם) wet granite; ( $\boldsymbol{\Delta}$ ) quartzdiorite; $(\bigcirc)$ wet peridotite; $(\diamond)$ dry peridotite.

and tensional stresses and, in each case, for dry and wet rocks. Total strength falls from $\sim 1.3 \times 10^{12}$ to $\sim 8 \times 10^{12} \mathrm{~N} \mathrm{~m}^{-1}$. In general, maximum total litho- spheric strengths were always associated with the lithosphere of the Duero Basin, while minimum values corresponded to that of the Central System. Under 


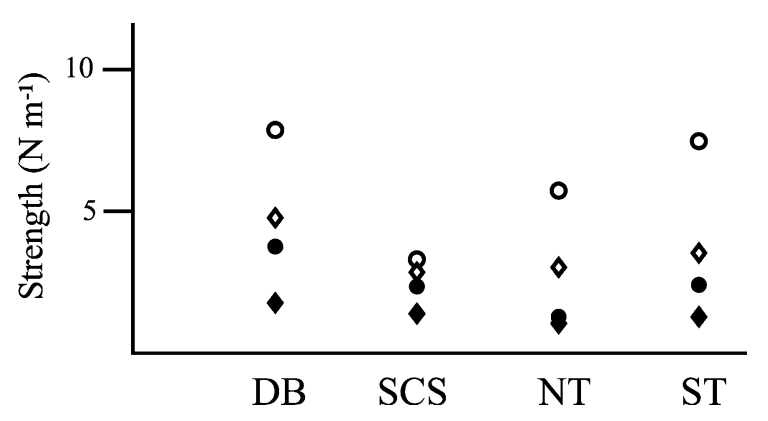

Fig. 4. Total lithospheric strength values for dry and wet rocks in compression and tension plotted for the different tectonic units. Higher strength values were obtained for dry rocks. Minimum strength values correspond to the Spanish Central System and the northern Tajo Basin. Estimations are made for compressive differential stress (open circles: dry rocks; open rhombus: wet rocks) and tensional differential stress (black circles: dry rocks; black rhombus: wet rocks). DB: Duero Basin; SCS: Spanish Central System, NT: Northern Tajo Basin, ST: Southern Tajo Basin.

tensional stress and for wet rocks, all areas showed minimum total strengths in the range $\sim 1.3 \times 10^{12}$ to $\sim 1.6 \times 10^{12} \mathrm{~N} \mathrm{~m}^{-1}$.

\section{Discussion}

Temperature- and strength-depth estimates indicate lateral variations in thermal structure and lithosphere rheology in the central Iberian Peninsula. Differences in crustal properties between the Central System and basin lithospheres give rise to different rheological profiles (Fig. 4). In general, except for the upper crust, ductile behaviour predominates in the crust and in the lithospheric mantle under compression stresses. Rheological profiles of the crust are similar for 60 and 65 $\mathrm{mW} \mathrm{m}^{-2}$ in the basins. Crustal thickening beneath the Central System and high heat flow in the northern zone of the Tajo Basin determine a higher Moho temperature and a larger span of ductile behaviour of the lithosphere. Discontinuities along the brittle and ductile layer give rise to lateral rheological anisotropy at the middle crust and Moho levels (Fig. 4). Given the extent of brittle and ductile layers, different rheological domains can be identified: the Duero Basin, the Central System and north and southern Tajo Basin zones.

As a first approximation, distribution of crustal seismicity can be taken as an indication of the extent of brittle layers (e.g., Sibson, 1982; Chen and Molnar,
1983; Meissner and Strelhau, 1982). Fig. 5 shows the distribution of earthquakes plotted on a digital elevation model of the area (Sánchez Serrano, 2000). Data were compiled from the Spanish Geographic Institute Catalogue (1961-2000); only earthquakes of magnitude up to 2.1 were considered. Maximum magnitude is 4.3. This is an area of relative seismic quiescence, where, taking into account the short time span recorded, seismicity is low, very low or even absent to the west. Seismic activity is mostly centred at the southern border fault of the Central System and in the east Tajo Basin (Fig. 5). The depth-frequency distribution of hypocentres shows them to be restricted to upper crustal depths (Fig. 5). Calculated hypocentre locations usually depend upon the reference crustal model used, and errors in focal depth estimations are common (errors reported here for focal depth estimates are $\sim 30 \%$ ). Bearing in mind these restrictions, we hypothesise general similarity between depth-frequency distribution and differential stress maxima (between 6- and 10-km depth) (Fig. 3). The lower crust is an earthquake-free zone. Although, few earthquakes occur below a $9 \mathrm{~km}$ depth and none below 23 $\mathrm{km}$, some involve depths characterised by ductile behaviour. Earthquake occurrence within ductile layers is a common problem, when earthquake depth distributions are compared through a first-order rheological approach. Heterogeneity in crustal structure and composition, discrepancies in rock properties and extrapolation of the frictional sliding law to depths greater than a few $\mathrm{km}$ are the main sources of uncertainty in rheological profile construction (e.g., Lachenbruch and Sass, 1992; Zoback and Healy, 1992; Cloetingh and Burov, 1996; Lamontagne and Ranalli, 1996).

An intriguing feature is the surface distribution of earthquakes. In the Duero and Tajo basins and western Central System, there is a lack of seismic activity. Seismotectonic activity is controlled by two essential factors: widespread regional field stress and preexisting zones of crustal weakness. From the Upper Miocene to the present, the Central Iberian Peninsula has suffered a stress field characterised by a maximum horizontal compressive stress in a NW-SE direction, which is the consequence of transmitted stresses from the Iberian Plate southern border resulting from convergence of the Iberian and African Plates (De Vicente et al., 1996a; Herraiz et al., 2000). Under the influence of large-scale tectonic stress, field movements occur 


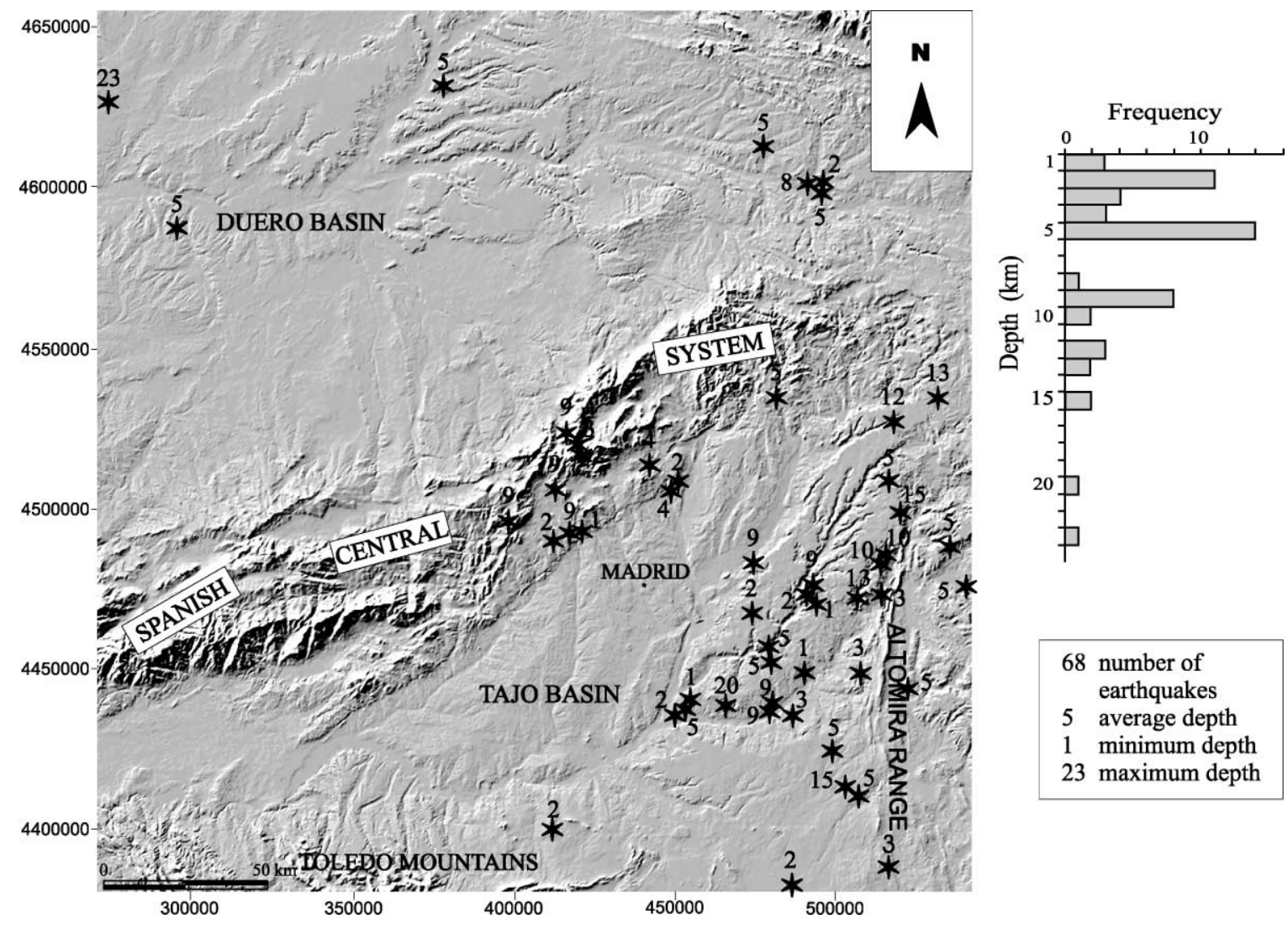

Fig. 5. Earthquake distribution superimposed on a digital elevation model of the study area. Earthquakes concentrate in the eastern area, mainly in the southeast Tajo Basin. Earthquake depth distribution shows that hypocentres are mainly restricted to upper crustal depths. U.T.M. coordinates in meters.

along inherited fault zones. In the study area, the Spanish Central System-Tajo Basin and Altomira Range-Tajo Basin boundaries represent zones of seismic activity related to crustal faults that border the tectonic units. The rheological profiles constructed predict rheological variation between the Central System and Tajo Basin. The southern border fault zone will be a rheological boundary, as well as a weakness zone. Although rheological stratification of the Altomira Range was not explored in this study, the Tajo Basin-Altomira Range boundary might be expected to correspond to a rheological discontinuity. It can be inferred that seismic activity could occur in major crustal weakness zones, being themselves sites of rheological discontinuities. Far from basin-range boundaries, seismic activity in the eastern part of the Tajo Basin has been explained as the effect of flexural bending stresses resulting from regional compression (De Vicente et al., 1996b; Giner, 1996; Andeweg et al., 1999). The higher span of ductile behaviour in the northern part of the Tajo Basin could imply that aseismic creep might be the main cause of release of cumulative strain.

If it is assumed that a seismic-aseismic boundary is related to the brittle-ductile boundary of the crust (e.g., Sibson, 1982; Meissner and Strehlau, 1982), changes in seismogenic thickness might be expected in the area under study. Constructed rheological profiles indicate that the Central System's southern border acts as a limit between rheological domains. Main seismic activity could take place in major structures related to boundary zones associated with rheological discontinuities, such as the boundary between the Central System and the Tajo Basin. 
A different problem arises from the lack of seismicity in the Duero Basin. Structural and palaeoseismic studies suggest different tectonic activity between the Duero and Tajo basins since as far back as the upper Miocene (De Vicente et al., 1996a). Structural and fission-track data show that deformation migrated from north to south over time (De Vicente et al., 1996a; De Bruijne and Andriessen, 1999). The uplift of the northern border of the Spanish Central System began earlier than at the southern border (De Bruijne and Andriessen, 1999). Although most deformation took place during the Miocene, there is well-documented evidence for shortening and uplift continuing into the Pliocene and Quaternary in the Tajo Basin (e.g., De Vicente et al., 1996a; Giner, 1996; Sánchez Serrano, 2000). Fault healing and lower horizontal stresses than necessary for elastic deformation could account for the lack of present-day activity. Total lithospheric strength gives maxima corresponding to the Duero Basin. Here, total lithospheric strength exceeds $2.5 \times 10^{12} \mathrm{~N} \mathrm{~m}^{-1}$, except for wet rocks in tension. For a lithosphere $100 \mathrm{~km}$ thick, this value is equivalent to a vertically averaged horizontal stress of the order of $25 \mathrm{MPa}$, assumed to be the upper threshold for deformation of the lithosphere (Kusznir and Park, 1984). From calculated total lithospheric strength values, it can be inferred that for wet rocks in tension and compression, the Tajo Basin and Central System are liable to fail; decreasing to $1.5 \times 10^{12} \mathrm{~N} \mathrm{~m}^{-1}$ for wet rocks in tension. Pore fluid pressure may play an important role in differential stress decline. At present, further seismic and structural data are needed to support this type of hypothesis.

\section{Conclusions}

The following conclusions may be drawn from our analysis of thermal state and rheological stratification of the lithosphere of the central Iberian Peninsula:

- Mantle heat flow increases with descending surface heat flow. The former ranges from $34 \mathrm{~mW}$ $\mathrm{m}^{-2}$ in the Duero Basin $\left(60 \mathrm{~mW} \mathrm{~m}^{-2}\right)$ to 27 and 29 $\mathrm{mW} \mathrm{m} \mathrm{m}^{-2}$ in the Tajo Basin $\left(70\right.$ and $65 \mathrm{~mW} \mathrm{~m}^{-2}$, respectively). In consequence, the lithosphere-asthenosphere boundary rises to $98 \mathrm{~km}$ to achieve a state of isostatic balance in the Duero Basin while, in the Tajo Basin, the boundary occurs at $110 \mathrm{~km}$.
- A difference in thermal state and crust structure gives rise to lateral rheological anisotropy. Calculated total lithospheric strength values show that highest strengths correspond to the Duero Basin and south Tajo Basin lithosphere.

- Hypocentres cluster in the crust correspond to the thickness of the competent crust layer. Seismicity appears to be related to major fault structures that bound rheological domains. The lack of seismicity north and westwards could be due to greater total lithospheric strength in these areas.

The Iberian plate interior consists of a crustal block mosaic resulting from extensive tectonic development. Differences in crustal structure and thermal state give rise to lateral anisotropy of crustal rheology. Further understanding of the links between rheology and present-day tectonic activity in the central Iberian Peninsula requires more detailed knowledge of crustal structure and thermal state. Further, different stress sources may be estimated, such as local stress-fields due to density heterogeneity.

\section{Acknowledgements}

We thank V. Cermak and two anonymous reviewers for their helpful comments and suggestions for improving the manuscript. The authors thank P. Villamor for her valuable comments and constructive revision of the manuscript, and Ana Burton for linguistic assistance. This work received financial support from the D.G.E.S. PB98-0846.

\section{References}

Aeroservice, 1964. Mapa aeromagnético de la Cuenca del Duero. Repport of Instituto Tecnológico y Geominero de España, Madrid.

Alonso, J.L., Pulgar, J.A., García-Ramos, J.C., Barba, P., 1996. Tertiary basins and the Alpine tectonics in the Cantabrian Mountains (NW Spain). In: Friend, P., Dabrio, C. (Eds.), Tertiary Basins of Spain. Cambridge Univ. Press, Cambridge, pp. 214-227.

Alvaro, M., Capote, R., Vegas, R., 1979. Un modelo de evolución geotectónica para la Cadena Ibérica Oriental. Acta Geol. Hisp. $14,172-177$.

Andeweg, B., De Vicente, G., Cloetingh, S., Giner, J., Muñoz Martín, A., 1999. Local stress fields and intraplate deformation of Iberia: variations in spatial and temporal interplay of regional stress sources. Tectonophysics $305,153-164$. 
Banda, E., Suriñach, E., Aparicio, A., Sierra, J., Ruiz de la Parte, E., 1981. Crust and upper mantle structure of the central Iberian Meseta (Spain). Geophys. J. Int. 67, 779-789.

Brace, W.F., Kohlstedt, D.L., 1980. Limits on lithospheric stress imposed by laboratory experiments. J. Geophys. Res. 85, 62486252.

Carter, N.L., Tsenn, M.C., 1987. Flow properties of continental lithosphere. Tectonophysics 136, 27-63.

Cermak, V., 1989. Crustal heat production and mantle heat flow in Central and Eastern Europe. Tectonophysics 159, 195-215.

Chen, W.P., Molnar, P., 1983. Focal depths of intracontinental and intraplate earthquakes and their implications for the thermal and mechanical properties of the lithosphere. J. Geophys. Res. 88, 4183-4214.

Cloetingh, S., Burov, B.E., 1996. Thermomechanical structure of European continental lithosphere: constraints from rheological profiles and EET estimates. Geophys. J. Int. 124, 695-723.

De Bruijne, C.H., Andriessen, P.A.M., 1999. Interplay of interplate processes in the Iberian Peninsula assessed by apatite fission track analysis. Abstract of the 11th Meeting of the Association of European Geological Societies, Instituto Tecnológico Geominero de España, p. 6.

De Vicente, G., González Casado, J.J., Bergamín, J.F., Tejero, R., Babin, R., Rivas, A.H., Enrile, J.L., Giner, J., Sánchez Seranno, F., Muñoz, A., Villamor, P., 1992. Alpine structure of the Spanish Central System. Actas, Tomo 1, III Cong. Geol. España y VIII Congr. Latinoamericano de Geología, pp. $284-$ 288.

De Vicente, G., Giner, J.L., Muñoz-Martín, A., González-Casado, J.M., Lindo, R., 1996a. Determination of present-day stress tensor and neotectonic interval in the Spanish Central System and the Madrid Basin, central Spain. Tectonophysics 266, 405-424.

De Vicente, G., González-Casado, J.M., Muñoz Martín, A., Giner, J., Rodríguez-Pascua, M.A., 1996. Structure and Alpine evolution of the Madrid basin. In: Friend, P., Dabrio, C. (Eds.), Tertiary Basins of Spain. Cambridge Univ. Press, Cambridge, pp. $175-190$.

Fernández, M., Marzán, I., Correia, A., Ramalho, E., 1998. Heat flow, heat production and lithospheric thermal regime in the Iberian Peninsula. Tectonophysics 219, 29-53.

Gallart, J., Fernández-Viejo, G., Díaz, J., Vidal, N., Pulgar, J.S., 1995. Deep structure of the transition between the Cantanbrian Mountains and the North Iberian Margin from wide-angle ESCIN data. Rev. Soc. Geol. España 8 (4), 365-382.

Giner, J.L., 1996. Análisi neotectónico y sismotectónico en la parte centro-oriental de la cuenca del tajo. PhD, Universidad Complutense, $250 \mathrm{pp}$.

Herraiz, M., De Vicente, G., Lindo-Ñaupari, R., Giner, J., Simón, J.L., González-Casado, J.M., Vadillo, O., Rodríguez-Pascua, M.A., Cicuéndez, J.I., Casa, A., Cabañas, L., Rincón, P., Cortés, A.L., Ramírez, M., Lucini, M., 2000. The recent (upper Miocene to Quaternary) and present tectonic stress distributions in the Iberian Peninsula. Tectonics 19 (4), 762-786.

Hyndman, R.D., Lewis, T.J., 1999. Geophysical consequences of the Cordillera-Craton thermal transition in southwestern Canada. Tectonophysics 306, 397-422.
ILIHA DSS Group, 1993. A deep seismic sounding investigation of the lithospheric heterogeneity and anisotropy beneath the Iberian Peninsula. Tectonophysics 221, 35-51.

Instituto Geográfico Nacional, 2001. Spanish Geographic Institute Catalogue (1961-1999). On-line service at www.mfom.es/ign/ top_geografico.html.

Kirby, S., Kronenberg, A.K., 1987. Rheology of the lithosphere: selected topics. Rev. Geophys. 25, 1219-1244.

Kusznir, N.J., Park, R.G., 1984. Intraplate lithosphere deformation and the strength of the lithosphere. Geophys. J.R. Astr. Soc. 79, 513-538.

Lachenbruch, A.H., 1968. Preliminary geothermal model of Sierra Nevada. J. Geophys. Res. 73, 6977-6989.

Lachenbruch, A.H., 1970. Crustal temperature and heat production: implications of the linear heat flow relation. J. Geophys. Res. $75,3291-3300$.

Lachenbruch, A.H., Morgan, P., 1990. Continental extension, magmatism and elevation; formal relations and rules of thumb. Tectonophysics $174,39-62$.

Lachenbruch, A.H., Sass, J.H., 1992. Heat flow from Cajun Pass, fault strength, and tectonic implications. J. Geophys. Res. 97, $4995-5015$

Lamontagne, M., Ranalli, G., 1996. Thermal and rheological constraints on the earthquake depth distribution in the Charlevoix, Canada, intraplate seismic zone. Tectonophysics 257, 55-69.

Lankreijer, A., Bielik, M., Cloetingh, S., Majcin, D., 1999. Rheology predictions across the western Carpathians, Bohemian massif and the Pannonian basin: implications for tectonic scenarios. Tectonics 18 (6), 1139-1153.

Lowe, C., Ranalli, G., 1993. Density, temperature, and rheological models for the southeastern Canadian Cordillera: implications for its geodynamic evolution. Can. J. Earth Sci. 30, 77-93.

Majorowicz, J.A., Jones, F.W., Lam, H.L., Jessop, A.M., 1984. The variability of heat flow both regional and with depth in southern Alberta, Canada: effect of groundwater flow? Tectonophysics $106,1-29$.

Meissner, R., Strehlau, J., 1982. Limits of stresses in continental crusts and their relation to the depth-frequency distribution of shallow earthquakes. Tectonics 1, 73-89.

Muñoz Martín, A., De Vicente, G., 1998. Origen y relación entre las deformaciones y esfuerzos alpinos de la zona centro-oriental de la Península Ibérica. Rev. Soc. Geol. España 11, 57-70.

Portero, J.M., Aznar, J.M., 1984. Evolución morfotectónica y sedimentación terciarias en el Sistema Central y cuencas limítrofes (Duero y Tajo). I Congr. Esp. Geol. 3, 253-263.

Pulgar, J.A., Gallart, J., Fernández-Viejo, G., Pérez-Estaún, A., Álvarez-marrón, J., 1996. Seismic image of the Cantabrian Mountains in the western extension of the Pyrenees from integrated ESCIN reflection and refraction data. Tectonophysics 264, 1-19.

Querol, R., 1989. Geología del subsuelo de la Cuenca del Tajo. E.T.S.I. Minas. Universidad Politécnica, Madrid, Spain, 48 pp.

Ranalli, G., 1997. Rheology of the lithosphere in space and time. In: Burg, J.P., Ford, M. (Eds.), Orogeny Through Time. Geological Society Special Publication, 121. Blackwell Science Publications, Oxford, pp. 19-37.

Ranalli, G., Murphy, D.C., 1987. Rheological stratification of the lithosphere. Tectonophysics 132, 281-295. 
Sánchez Serrano, F., 2000. Ánálisis de la Topografía y Deformaciones Recientes en el Centro de la Península Ibérica. PhD thesis, Univ. Complutense de Madrid, Spain, pp. 1-202.

Santisteban, J.I., Mediavilla, R., Martín-Serrano, A., Dabrio, C.J., 1996. The Duero Basin: a general overview. In: Friend, P., Dabrio, C. (Eds.), Tertiary Basins of Spain, Cambridge Univ. Press, Cambridge, pp. 255-259.

Sibson, R.H., 1974. Frictional constraints on thrust, wrench and normal faults. Nature 249, 542-544.

Sibson, R.H., 1982. Fault zone models, heat flow, and the depth distribution of earthquakes in the continental crust of the United States. Bull. Seismol. Soc. Am. 72, 151-163.

Suriñach, E., Vegas, R., 1988. Lateral inhomogeneities of the Hercyninan crust in central Spain. Phys. Earth Planet. Inter. 51, 226-234.

Tejero, R., Perucha, A., Rivas, A., Bergamín, J.F., 1996. Modelos estructural y gravimétrico del Sistema Central. Geogaceta 20, 947-950.

Tsenn, M.C., Carter, N.L., 1987. Upper limits of power law creep of rocks. Tectonophysics 136, 1-26.

Vegas, R., Vázquez, J.T., Suriñach, E., Marcos, A., 1990. Model of distributed deformation, block rotations and crustal thickening for the formation of the Spanish Central System. Tectonophysics 184, 367-378.

Viallard, P., 1983. Le décollement de la couverture dans la Chaîne Ibérique méridionale: effect de raccourcissements différentiels entre substratum et couverture. Bull. Soc. Geol. France 25, $379-383$.

Villaseca, C., Downes, H., Pin, C., Barbero, L., 1999. Nature and composition of the Lower Continental Crust in Central Spain and the Granulite-Granitic Linkage: inferences from granulitic Xenoliths. J. Petrol. 40 (10), 1463-1496.

Warburton, J., Álvarez, C., 1989. A thrust tectonic interpretation of the Guadarrama Mountains, Spanish Central System. In: Libro Homenaje a Rafael Soler. Asoc. Geol. Geof. Esp. del Petróleo, Spain, pp. 147-155.

Zeyen, H., Fernández, M., 1994. Integrated lithospheric modeling combining thermal, gravity and local isostasy analysis: application to the NE Spanish Geotransect. J. Geophys. Res. 99 (B9), 18089-18102.

Zoback, M.D., Healy, J.H., 1992. In situ measurements to $3.5 \mathrm{~km}$ depth in the Cajun Pass scientific research borehole: implication for the mechanics of crustal faulting. J. Geophys. Res. 97, $5039-5057$. 